\title{
THE PRESPA AGREEMENT BETWEEN MACEDONIA AND GREECE AND POSSIBLE FURTHER ACTION(S) RELATED TO VALIDITY OF THE TREATY
}

\author{
Igor JANEV, ${ }^{1}$ \\ Institute of Political Studies, Belgrade
}

\begin{abstract}
In the present article we discuss the future and prospects of the Prespa Agreement, concluded on June 17, 2018, between Macedonia and Greece aiming at resolving their "difference" over the name of Macedonia. The analysis is carried out by examining the legal aspects of United Nations Security Council Resolution 817 (1993) recommending the admission of Macedonia to UN membership but imposing on the applicant a provisional name (pending the settlement of difference over the applicant's name), in particular its legal consistence with the provisions of Vienna Convention on the Law of Treaties (1969) and with the general jus cogens norms of International Law enshrined in the UN Charter. It is concluded that the UN SC Res .817 (1993) is by itself an ultra vires act and cannot serve as a legal basis for the Prespa Agreement (ex injuria jus not oritur), that the Prespa Agreement violates the provisions of the Vienna Convention on the Law of Treaties and the peremptory norms of International Law, particularly the principle of self-determination and enters into legal matters that belong stricto sensu to the domain of domestic jurisdiction of Macedonia. For these reasons the Prespa Agreement cannot be considered a legally valid treaty and, consequently, and Agreement can be subject of unilateral termination under provisions of Vienna Convention on the Law of Treaties (1969). The appropriate measure of actions in the case of illegal treaty is to terminate the Agreement with a diplomatic note, as a unilateral legal act expressing a will of the state.
\end{abstract}

Keywords: UN Charter, Prespa Agreement, Vienna Convention of the Law of Treaties, self-determination of peoples and States, inviolability of domestic jurisdiction, juridical personality.

\section{Introduction}

The Prespa Agreement (PA) between Macedonia and Greece, reached on 12 June 2018 near the Prespa Lake, under the auspices of United Nations and relates to the resolution of long-standing so called "dispute" between the two countries over the name of Macedonia. The official title of the agreement reads: "Final agreement for the settlement of the differences as described in the United Nations Security Council resolutions 817 (1993) and 845 (1993), the termination of the Interim Accord of 1995, and the establishment of a strategic partnership between the parties". It indicates that the Agreement is based on the accepted (or assumed) legality of the UNSC Resolution 817 (1993). The subject matter of the Prespa Treaty is defined more precisely in the

1 Contact address: igorjanev@mts.rs. 
Preamble: "Resolving the difference pursuant to Security Council resolutions 817 (1993) of 7 April 1993 and 845 (1993) of 18 June 1993, [as well as Article 5 of the Interim Accord of 13 September 1995] in a dignified and sustainable manner, having in mind the importance of the issue and the sensitivities of each Party, ...". The issue of "difference" (over the name Macedonia) was created by the Greek allegation raised during the process of admission of Republic of Macedonia to UN membership that the name of the applicant implies "territorial claims towards Greece". Despite the fact that Republic of Macedonia has amended its constitution in 1992, (affirming that it "has no territorial claims against any of neighboring states", and that its borders can only be changed in accordance with the Constitution and "generally accepted international norms"), the Security Council in its Res. 817 (1993), after affirming that "the applicant fulfils the criteria for membership laid down in Article 4 of the Charter of the United Nations", has nevertheless added that the applicant state shall be "provisionally referred to for all purposes within United Nations as 'the former Yugoslav Republic of Macedonia', pending settlement of the difference that has arisen over the name of the state" (UNSCR (07/04/1993) Resolution 817). The second part of the above sentence implies an obligation on the new UN member to negotiate over its name with a neighboring state (Greece). Both imposed conditions on Macedonia at the moment of its admission (namely: (i) to accept a provisional name for all purposes within UN and (ii) to negotiate with Greece over its name), defining its UN Membership status, are in sharp violation of Article 2(1) ("sovereign equality of Members") of UN Charter. Moreover, the provision in SC Res. 817 (1993) that the applicant should negotiate over its name with another state is in violation with Article 2(7) of the UN Charter prohibiting United Nations to intervene in matter of the domestic jurisdiction of states ("Nothing contained in the present Charter shall authorize the United Nations to intervene in matters which are essentially within the domestic jurisdiction of any state"). The condition (ii) is also in violation with Article 1(2) of the Charter (the principle of "equal rights and self-determination of peoples"). The violations of Articles 1(2), 2(1) and 2(7) of the UN Charter in SC Res.817 (1993) represent serious breaches of the Charter. We note that the UN General Assembly admitted Macedonia to UN membership (GA Res. 47/225 (1993)) on the basis of SC Res. 817 (1993) (with the addition conditions therein).

\section{The "legal grounds" of Prespa Agreement}

The SC Res. 817 (1993), by imposing two additional conditions (obligations) on the applicant state for its admission to UN Membership, (after affirming that the applicant meets "the criteria for membership laid down in Article 4 of the Charter of the United Nations") is in severe conflict with the Advisory Opinion of International Court of Justice (ICJ) of May 28, 1948, related to the conditions required for admission of a state to UN membership, and accepted by the General Assembly in its resolution A/RES/197(III) on December 8, 1948. ${ }^{2}$ The opinion of the International Court of Justice was that "the conditions stated in paragraph 1 of Article 4 must be regarded

2 Advisory Opinion of International Court of Justice (ICJ) of May 28, 1948. By definition, a legal norm may not contain indefinite set of conditions (or obligatory legal elements). 


\section{Sececurity}

not merely as necessary conditions, but also as the conditions which suffice" (for admission). Furthermore, it stated: "Nor it can be argued that the conditions enumerated (in paragraph 1 of Article 4) represent an indispensable minimum, in the sense that political considerations could be superimposed upon them, and prevent the admission of an applicant which fulfils them". Hence, the conditions laid down in paragraph 1 of Article 4 of the UN Charter are exhaustive, necessary and sufficient and, if fulfilled appropriately in Security Council's opinion, the applicant state must be unconditionally admitted to UN membership. As mentioned above, this legal interpretation of Article 4(1) of the Charter by the Court was accepted by the General Assembly in its resolution A/RES/197(III) of December 8, 1948. In view of the accepted Court's interpretation of Article 4(1) and of its acceptance by the General Assembly in 1948, it follows that the resolutions SC Res. 817 (1993) and GA Res. 47/225 (1993) with the additional conditions imposed on Macedonia at its admission to UN membership are in violation with Article 4 (1) of the Charter as a legal norm. As mentioned above, the introduction of the additional conditions (i) and (ii) for the admission of Macedonia to UN membership was based on the Greek allegation that the name of the applicant "implies territorial claims" were reflected in the wording of both resolutions as "difference over the name". However, according to the international law no state has an exclusive right over a name and that the "Greek demand that Macedonia change its name has no basis in the international law and practice" (Henkin et al., 1993). Indeed, as argued by Janev (1999), based on the principle of separability of domestic and international jurisdictions, the name of a state, which is subject to that state's domestic jurisdiction, does not create international legal rights for that state, nor does it impose legal obligations on other states. Clearly, the name per se does not have a direct impact on the territorial rights of states. Therefore, the Greek allegation that the name of the applicant implies "territorial claims" has no legal significance. Interference with matters that are essentially within the domestic jurisdiction of a state, such as the choice of state's name, is also incompatible with Article 1(2) of the UN Charter ("self-determination of peoples"). Article 2 (7) of the Charter explicitly extends the validity of this legal norm to the United Nations themselves. It appears, therefore, that the Greek opposition to the admission of Macedonia to UN membership under its constitutional name and the intervention of the UN Security Council in the matters related to the name of the applicant state, are inconsistent with the Charter.

The inherent right of a state to have a name can be derived from the necessity that a juridical person must have a legal identity. In absence of such identity, the juridical person, such as a state, could to a large extent loose its capacity to interact with other juridical persons (e.g., conclude agreements, etc.) and independently enter into and conduct its external relations. The name of a state is, thus, an essential element of its juridical personality and of its statehood. The principles of sovereign equality of states and the inviolability of their juridical personality led to the conclusion that the choice by a state of its own name is a basic, inherent right of the state. This right is not alienable, divisible or transferable. It is an essential part of the right to 'self-determination' (determination of one's own legal identity), i.e., it belongs to the domain of jus cogens norms. External interference with this basic right is inadmissible. It is also obvious that if such an external interference with the choice of the name of a state would be allowed, 
even though a negotiation process, it might easily become a legally endorsed mechanism for interference in the internal and external affairs of that state, i.e., a mechanism for degradation of its political independence. From these reasons, the choice by the state of its own name must be considered as an inherent right of the state that stricto sensu belongs to the domain of its domestic jurisdiction. In exercising this right, the states have, therefore, a complete legal freedom. This freedom may in practice be constrained only by considerations of avoidance the overlap of legal identities of two (or more) international juridical persons. (The province 'Macedonia' in Northern Greece is, however, not an international juridical person).

The imposition of two additional conditions on Macedonia at the time of its admission to membership to United Nations (to accept a provisional name for use within the UN system and negotiate with Greece over its name), outside those exhaustively enumerated in Article 4(1) of the Charter, represents a breach of the Charter provisions and, therefore, are an ultra vires act. They also violate Article 1(2) of the Charter (the principle of "equal rights and self-determination of peoples"). It is important to note that these conditions transcend the time of the admission act and define a membership status which is also in violation with the provisions of paragraphs 1 and 7 of Article 2. The condition for acceptance of a provisional name is also in violation with Article 83 of the "Vienna Convention on the Representation of States in their Relations with the International Organizations of Universal Character" of March 14, 1975, dealing with the issue of non-discrimination of states in these relations. A legal identity (or a name) of a State by definition is an essential element of both internal (domestic) and international legal personality of a State, and may not be subject of any intervention (particularly not by external acts, such as agreements or resolutions). Furthermore, international legal personality appears to be an essential element of a Statehood itself.

The derogated UN membership status of Macedonia and the breaches of the UN Charter provisions by the resolutions SC Res. 817 (1993) and GA Res. 47/225 (1993)3 , as well as their juridical redress, have been discussed in several literature papers. The legal responsibility of the United Nations for violation of Charter's provisions stems from the UN duty to respect the basic rights of the states (either as applicants or UN members), which are protected by the principles of international law enshrined in the mentioned articles of the Charter. The juridical redress of the UN Charter violations in SC Res. 817 (1993) and GA Res. 47/225 (1993) resolutions can only be carried out through the International Court of Justice by reaffirming its own advisory opinion of May 28, 1948 and recalling the General Assembly resolution A/RES/197 (III) of December 8, 1948 (Janev and Petrovic, 2011).

The condition regarding negotiations with Greece ("speedy settlement of the difference over the name") needs a more detailed analysis. It is an obligation imposed on Macedonia whose fulfillment depends on another country and is, therefore, outside of its control. The obligation for "the settlement of the difference over the name" is carried only by one of the parties involved, while the other party has a full freedom and control over the negotiating process. Indeed, in the

3 UNGA Res. 47/225 Admission of the State whose application is contained in document A/47/876-S/25147 to membership in the United Nations (1993). 
course of negotiations over 25 years, mediated by a UN Special Representative, Greece has been repeatedly obstructing the negotiations by ever-expanding its demands. In later years of negotiating process, the Greek demands started to include more and more matters which are strictly within the domain of domestic jurisdiction of Macedonia (significant changes to the Constitution, demands relating to the use of Macedonian language and redefinition of national identity) and will be discussed in more detail in the next Section. Here we only note that these demands are completely outside of the initial legal frame of the subject of negotiations, formulated by the SC Res. 817 (1993) and in the latest stage of the negotiation process took the form of an ultimatum.

Thus, the illegal conditions imposed on Macedonia for its admission to UN membership relating to the provisional name of the state and the "settlement of the difference" over its name generated a serious long-term problem in the relations between Macedonia and Greece, threatening Macedonian people to lose their national identity. It should be noted that before its admission to the UN membership in 1993, Macedonia had been recognized by its constitutional name Republic of Macedonia by 30 sovereign states. As a UN member, its legal personality has been given a provisional denomination 'The Former Yugoslav Republic of Macedonia" for use within the UN system. However, due to the authority of the UN "recognition" many countries and international organizations have recognized it with the UN denomination. It is further worth noting that many countries have recognized it by its constitutional name, neglecting the UN denomination. The total number of UN member states which recognized Macedonia by its constitutional name before the conclusion of Prespa Agreement was 134 . This number by itself $(69.4 \%$ of the total UN membership) can serve as an indication of the baselessness of legal, political and historic arguments of Greece for the change of constitutional name of Macedonia, as well as of the illegality of related UN SC 917 (1993) and GA 47/225 (1993) resolutions. As mentioned earlier, there is no legal basis in the international law and practice for the Greek demands (Henkin et al., 1993). The Security Council was apparently completely ignorant of this fact and, more importantly, of the legal interpretation of Article 4(1) of the Charter given in the 1948 Advisory Opinion of the International Court of Justice, another principal organ of the United Nations. Irrespective whether a result of ignorance or politically motivated inclination, the additional conditions represent a severe violation of the legal norms enshrined in the UN Charter Articles $1(2), 4(1), 2(1,7)$, producing dramatic negative consequences for its membership status and its external political relations. In conclusion, UNSC Res. 817 clearly represents an ultra vires act of the United Nations and violates the general principles International Law (the jus cogens norms). For these reasons, the UNSC Res. 817(1993), as well as the related GA 47/225 (1993), cannot be considered as legally valid documents on the basis of which another legally valid document can be created (the legal principle ex injuria, jus non oritur). It cannot serve as a basis for any kind of an "ID agreement ", that appears to be a consequence or the final result of the mentioned additional conditions imposed on the candidate for UN membership. 


\section{Sececurity}

\section{The Prespa Agreement and the International Law}

In the Preamble of the Vienna Convention on the Law of treaties (1969) it is stipulated that the State Parties of the Convention are "having in mind the principles of international law embodied in the Charter of United Nations, such as the principles of equal rights and self-determination of peoples, the sovereign equality and independence of States, of non-interference in the domestic affairs, [.... $]$, and of universal respect for, and observance of, human rights and fundamental freedoms for all".

In the Preamble of PA is also stipulated that the Parties of the Agreement are: "Guided by the spirit and principles of democracy, respect for human rights and fundamental freedoms, and dignity", and "Abiding by the provisions of the Charter of the United Nations".

However, already in the first sentence of the Preamble of PA, the Parties of the Agreement are treated as un-equal: the First Party is identified by its constitutional name (Hellenic Republic), while the Second Party is identified as the state "which was admitted to the United Nations in accordance with the United Nations General Assembly resolution 47/225 of 8 April/1993". This un-equal representation of the treaty Parties already in the Treaty Preamble is a violation of the principle of "sovereign equality" of states and inobservance of the dignity of the Second Party. This un-equal position of the Parties remains throughout the text of the Treaty.

The PA contains three parts of which only the first one (containing eight articles) deals with the name issue; the other two regulate matters of bilateral character (economic, political and cultural relations and establishment of a "strategic partnership") (Final Agreement, 2018).

In paragraph 2 of Article 1, "The Parties recognize as binding the outcome of the negotiations that have taken place under the auspices of the United Nations, to which both Parties have been committed pursuant to the United Nations Security Council resolutions 817 (1993) and 845 (1993) [as well as the Interim Accord of 1995] ". We note that SC Res. 845 (1993) "urges the parties to continue their efforts to arrive at a speedy settlement of the remaining issues between them". The wording "remaining issues" in the interpretation of the First Party of PA does not mean only "differences over the name" but extends to matters of national identity, state language, constitution and even the internal administrative system. The Greek interpretation of the provisions of SC Res.845 (1993) is fully arbitrary and goes far beyond the original scope of the negotiations for "settlement of differences over the name" as defined by the SC Res. 817 (1993) and GA 47/225 (1993) (which, as already discussed earlier, violate the UN Charter). Nevertheless, this Greek interpretation of SC resolutions 817 (1993) and 845 (1993) is thoroughly reflected in all eight articles of Part I of PA. The tone and the wording of the provisions of this part of the Agreement are reminiscent to those of a peace treaty dictated by the party winning the war to the one that had lost the war. This can be illustrated by the text of paragraph 3 of Article 1 of the Agreement, where the treaty obligations of the Second Party are enumerated:

"Pursuant to those negotiations the following have been mutually accepted and agreed:

a) The official name of the Second Party shall be the "Republic of North Macedonia", which shall be the constitutional name of the Second Party and shall be used erga omnes, as provided for in this Agreement. The short name of the Second Party shall be "North Macedonia". 
b) The nationality of the Second Party shall be Macedonian/citizen of the Republic of North Macedonia, as it will be registered in all travel documents.

c) The official language of the Second Party shall be the "Macedonian language", as recognized by the Third UN Conference on the Standardization of Geographical Names, held in Athens in 1977, and described in Article 7(3) and (4) of this Agreement.

d) The terms "Macedonia" and "Macedonian" have the meaning given under Article 1(7) of this

Agreement.

e) The country codes for licenses plates of the Second Party shall be NM or NMK. For all other purposes, country codes remain MK and MKD, as officially assigned by the International Organization for Standardization ("ISO").

f) The adjectival reference to the State, its official organs, and other public entities shall be in line with the official name of the Second Party or its short name, that is, "of the Republic of North Macedonia" or "of North Macedonia". Other adjectival usages, including those referring to private entities and actors, that are not related to the State and public entities, are not established by law and do not enjoy financial support from the State for activities abroad, may be in line with Article 7(3) and (4). The adjectival usage for activities may be in line with Article 1(7) (-3) and (-4). This is without prejudice to the process established under Article $1(3)(\mathrm{h})$ and compound names of cities that exist at the date of the signature of this Agreement.

g) The Second Party shall adopt "Republic of North Macedonia" as its official name and the terminologies referred to in Article 1(3) through its internal procedure that is both binding and irrevocable, entailing the amendment of the Constitution as agreed in this Agreement. ${ }^{4}$

h) In relation to the above-mentioned name and terminologies in commercial names, trademarks and brand names, the Parties agree to support and encourage their business communities to institutionalize a sincere, structured and in good faith dialogue, in the context of which will seek and reach mutually accepted solutions on the issues deriving from the commercial names, the trademarks, the brand names and all relevant matters at bilateral and international level. For the implementation of the above-mentioned provisions, an international group of experts will be established consisting of representatives of the two States in the context of the European Union ("EU") with the appropriate contribution of the United Nations and ISO. This group of experts shall be established within 2019 and conclude its work within three years. Nothing in Article $1(3)$ (h) shall affect present commercial usage until mutual agreement is reached as provided in this subsection".

It is obvious from the above that the First Party essentially dictates the treaty provisions, while the Second Party needs only to accept them. The inequality of Treaty Parties is obvious, despite of their equal legal status under the International Law. Even some Greek authors agree

4 It should be noted at this point that Constitution of the Republic of Macedonia had expressly provided that all treaties and agreements concluded by the Macedonian Government or a President must be in accordance with the Constitution, as a higher act, and not subjected to conditions of any treaty. 
with this conclusion (Heraclides, 2020). The Second Party obviously has a subordinate position with respect to the First one. ${ }^{5}$

The core provisions b) and c) of paragraph 3 are essentially beyond the scope of the subject of the Agreement defined by SC Res. 817 ("settlement of difference" over the name) and relate to the matters of national identity and language. As mentioned in sub-paragraph (3-f) above the meaning of the noun "Macedonia "and the adjective "Macedonian" is provided by the provisions of Article 7 the first three paragraphs of which read:

The Parties acknowledge that their respective understanding of the terms "Macedonia" and "Macedonian" refers to a different historical context and cultural heritage.

2. When reference is made to the First Party, these terms denote not only the area and people of the northern region of the First Party, but also their attributes, as well as the Hellenic civilization, history, culture, and heritage of that region from antiquity to present day.

3. When reference is made to the Second Party, these terms denote its territory, language, people and their attributes, with their own history, culture, and heritage, distinctly different from those referred to under Article 7(2).

The provisions 2 and 3 deprive the terms "Macedonia" and "Macedonian" from their general meaning, framing them within a historic, cultural or regional context. This a severe derogation of the Macedonian identity and Macedonian language; it represents a flagrant negation of the rights to national identity, culture and language of the Macedonian minority in Greece and the other countries. Like the state name, the identity of a people, its culture and language are indivisible, non-transferable and non-alienable. Therefore, the Articles 1(3-f) and Article 7 are in violation with the general norms of International Law, including those related to the minority rights.

In the remaining paragraphs 4-13 of Article 1 the implementation of the provisions of Article 1(3) are stipulated, again in an ultimate form, with the First Party playing the oversighting role.

Upon signing this Agreement, the Parties shall take the following steps:

a) The Second Party shall, without delay, submit the Agreement to its Parliament for ratification.

b) Following ratification of this Agreement by the Parliament of the Second Party, the Second Party shall notify the First Party that its Parliament has ratified the Agreement.

c) The Second Party, if it decides so, will hold a referendum.

d) The Second Party shall commence the process of constitutional amendments as provided for in this Agreement.

e) The Second Party shall conclude in Toto the constitutional amendments by the end of 2018 .

f) Upon notification by the Second Party of the completion of the above-mentioned constitutional amendments and of all its internal legal procedures for the entry into force of this Agreement, the First Party shall promptly ratify this Agreement.

5. Upon entry into force of this Agreement, the Parties shall use the name and terminologies of Article 1(3) in all relevant international multilateral and regional Organizations, institutions

5 It should also be noticed that according to Article 20 (9) of the Prespa Agreement "no modification to this Agreement contained in Article 1(3) and Article 1(4\} is permitted." Namely, it was stipulated here that "the provisions of this Agreement shall remain in force for an indefinite period of time and are irrevocable." 
and fora, including all meetings and correspondence, and in all their bilateral relations with all Member States of the United Nations.

6. In particular, immediately upon entry into force of this Agreement, the Second Party shall:

a) Notify all international, multilateral and regional Organizations, institutions and fora of which it is a member of the entry into force of this Agreement, and request that all those Organizations, institutions and fora thereafter shall adopt and use the name and terminologies referred to in Article 1(3) of this Agreement for all usages and purposes. Both Parties shall also refer to the Second Party in accordance with Article 1(3) in all communications to, with, and in those Organizations, institutions and fora.

b) Notify all Member States of the United Nations of the entry into force of this Agreement and shall request them to adopt and use the name and terminologies referred to in Article $1(3)$ of this Agreement for all usages and purposes, including in all their bilateral relations and communications.

7. Upon entry into force of this Agreement, and subject to provisions under Articles 1(9) and (10), the terms "Macedonia", "Republic of Macedonia", "FYR of Macedonia", "FYR Macedonia" in a translated or untranslated form, as well as the provisional name "the former Yugoslav Republic of Macedonia" and the acronym "FYROM" shall cease to be used to refer to the Second Party in any official context.

8. Upon entry into force of this Agreement and taking into account its Article 1(9) and (10), the Parties shall use the name and terminologies of Article 1(3) for all usages and all purposes erga omnes, that is, domestically, in all their bilateral relations, and in all regional and international Organizations and institutions. ${ }^{6}$

9. Upon entry into force of this Agreement, the Second Party shall promptly in accordance with sound administrative practice take all necessary measures so as the country's competent Authorities henceforth use internally the name and terminologies of Article 1(3) of this Agreement in all new official documentation, correspondence and relevant materials.

10. As regards the validity of already existing documents and materials issued by the Authorities of the Second Party, the Parties agree that there shall be two transitional periods, one "technical" and one "political":

a) The "technical" transitional period shall relate to all official documents and materials of the Public Administration of the Second Party for international usage and to those for internal usage that may be used externally. These documents and materials shall be renewed in accordance with the name and terminologies as referred to in Article 1(3) of this Agreement within five years from the entry into force of this Agreement, at the latest.

b) The "political" transitional period shall relate to all documents and materials exclusively for internal usage in the Second Party. The issuance of the documents and materials falling under this

6 In practice, that would mean denouncement of a policy of national recognition under present constitutional name, and public global request to recognition under condition that provided by the Prespa Agreement, including a prefix before Macedonia, that has to be used by all subjects in international community. 
category in accordance with Article 1 (3) shall commence at the opening of each EU negotiation chapter in the relevant field, and shall be finalized within five years thereof.?

11. Procedures for the prompt amendment of the Constitution of the Second Party, in order to fully Implement the provisions of this Agreement, shall commence upon ratification of this Agreement by Its Parliament or following a referendum, If the Second Party decides to hold one.

12. The name and terminologies as referred to in Article 1 of this Agreement shall be incorporated in the Constitution of the Second Party. This change shall take place a bloc with one amendment. Pursuant to this amendment, the name and terminologies will change accordingly in all articles of the Constitution. Furthermore, the Second Party shall proceed to the appropriate amendments of Its Preamble, Article 3 and Article 49, during the procedure of the revision of the Constitution.

13. In the event of mistakes, errors, omissions in the proper reference of the name and terminologies referred to in Article 1(3) of this Agreement in the context of international multilateral and regional Organizations, institutions, correspondence, meetings and fora, as well as in all bilateral relations of the Second Party with third States and entities, either of the Parties may request their immediate rectification and the avoidance of similar mistakes in the future.

It should be noted that the implementation of the provisions of Article 1(3) requires amendments of the Constitution of the Second Party, paragraphs $4(\mathrm{~d}, \mathrm{e}), 11$ and 12 , and the use of the new name and related terminologies shall be used for all proposes erga omnes (i.e. internally and externally) by both Parties (Article 1(8)).8

The provisions of Article $1(3-a,-b,-c)$ related to the name, national identity and the language, respectively, of the Second Party, and the provisions of Article 7(1-5) providing historic, territorial and cultural restrictions to their use, and thereby severely derogating their meaning, as well the provisions of Articles 1(4), 1(11) and 1(12) imposing explicitly revision and amendments to the Constitution of the Second Party, are obviously in conflict with the peremptory norms of International Law and Article 53 of the Vienna Convention on the Law of Treaties (1969). For this reason, the PA can be considered as null and void, and a subject of unilateral termination.

As argued earlier the state name and national identity are essential parts of the inalienable right of peoples to self-determination. Moreover, the national identity is by its nature an unchangeable inherent category. It is a self-identification of a group of people built through a common history, sharing the same language, customs, believes, ethical norms and having the same aspirations. It is a social phenomenon existing essentially outside of the realm of the Law. The main psychological characteristic of the members such a social group is their individual and collective conciseness of their "belonging" (to the group). The name is only linguistic or a formal description of such social group, most often related to the geographical name of the territory it occupies. Therefore,

\footnotetext{
7 Basically, operation of the agreement is dependent on the external and internal conditions and developments, including EU negotiations achievements and a future will of the people and the political will of the government to accept long-lasting ID redefinition (s).

8 Irrevocable provisions contained in the paragraphs 3. and 4. of the Article 1, apparently serves as permanent ID modifiers of the original national / state identity. Agreement itself dictates imposition of amendments to the Constitution (that needs to be in accordance with the Agreement, and not vice versa).
} 
both the national identity and the name per se, cannot be subject to negotiation or imposition. The population of Macedonian nation on the territory of present Macedonia has been carrying that name and national sentiment for centuries, politically expressed during the long struggle for independence from the Ottoman rule and the occupation by the neighboring Balkan states, finally achieving its statehood at the 1st session of ASNOM (Anti-fascist Assembly for National Liberation of Macedonia) on September 2, 1944. The national self-determination of the Macedonian people with the Macedonian language as state language were proclaimed at ASNOM and re-affirmed in the first Constitution (1946) of the People's Republic of Macedonia, as constitutive unit of the Federal People's Republic of Yugoslavia, as well as in the Constitutions of Socialist Republic of Macedonia (1963) (constitutive unit of the Socialist Federative Republic of Yugoslavia- SFRY) and of independent Republic of Macedonia (1991) after the dissolution of SFRY.

Perhaps the most unusual, and apparently outside the legal framework of International Law, is the establishment by the Article 8(5) of Prespa Agreement, 'on a parity basis', a Joint Inter-Disciplinary Committee of Experts on historic, archaeological and educational matters, to consider the objective, scientific interpretation of historical events based on authentic, evidence-based and scientifically sound historical sources and archaeological findings.

The Committee's work shall be supervised by the Ministries of Foreign Affairs of the Parties in cooperation with other competent national authorities. It shall consider and, if it deems appropriate, revise any school textbooks and school auxiliary material such as maps, historical atlases, teaching guides, in use in each of the Parties, in accordance with the principles and aims of UNESCO and the Council of Europe. To that effect, the Committee shall set specific timetables so as to ensure in each of the Parties that no school textbooks or school auxiliary material in use the year after the signing of this Agreement contains any irredentist/revisionist references. The Committee shall also study any new editions of school textbooks and school auxiliary material as provided for under this Article. The Committee shall convene regularly, at least twice a year, and shall submit an Annual Report on its activities and recommendations to be approved by the High-level Cooperation Council, as to be established pursuant to Article $12 .{ }^{9}$

This provision is far from the legal standards of sovereign rights of states, provides a mechanism for revision of the cultural history of the Second Party and permanent intervention and control of its cultural and educational policies, hence severely derogating its sovereign cultural rights and sovereign identity. The mentioned principle relating to collective human rights as a rule of self-determination is also applicable to the rights of States. Namely, States has a right to self-determination, particularly to self-identification and juridical equality vis-à-vis other sovereign states. A link between the name of the State and a general category of a national identity (as a collective human right) lies in the category of legitimacy that means original sovereign people's will and consent to freely refer to itself and to self-identify (itself or themselves) as a people or as a nation, in accordance with the basic principle of sovereign people's will (i.e. principle of a popular sovereignty).

9 See articles 8. and 12. of the Agreement. 


\section{Seccurity}

\section{Conclusions}

In the present article we have analyzed sustainability and legality of the PA concluded between Macedonia and Greece on June 12, 2018, aiming at resolving the 25-year long dispute between the two countries over the name of Macedonia. We have analyzed the legal basis and aspects of the UN SC Resolutions 817(1993 and 845 (1993) in which the name "dispute" was imposed on Macedonia as a condition during its admission to UN membership, together with the condition to accept a provisional name 'The Former Yugoslav Republic of Macedonia' for use within the UN system. We have argued that imposing of additional in SC 817 conditions to an applicant state, after affirming that the applicant fulfills the admission conditioned laid down in Article 4(1) of the UN Charter is in severe violation with the Advisory opinion of the International Court of Justice of 28 May 1948, of 1948, accepted by the General Assembly Resolution 197/III of 1948. In view of these two UN documents the SC Res. 817(1993) is in breach with the UN Charter Articles 1(2), 2(1), 2(7) and 4(1), the first three belonging jus cogens norms of international law. The SC Res. 817 is therefore an ultra vires act, breaching the peremptory norms of internal law and cannot serve as legal basis for the Prespa Agreement (or for any other treaty according to general legal principle ex injuria jus non oritur).

The PA is by itself in conflict with jus cogens norms of international law and enters in legal matters that belong stricto sensu in the domain of the domestic jurisdiction of the other party. Its provisions even provide mechanisms for permanent intervention into internal and external affairs of the Second Party, derogating its human (dignity) and cultural rights and freedoms, and the basic rules of non-discrimination. Therefore, the Prespa Agreement violates Article 53 of the Vienna Convention on the Law of Treaties.

The non-binding referendum in Macedonia, held on 30 September 2018 with a turnout of only $37 \%$ (due to the mass popular boycott) whose question about the change of the name was explicitly associated with the presumption for access to EU and NATO, was a clear indication of the citizens' negative attitude to the Agreement. The political manipulations within the Macedonian Parliament and the open political pressures exercised by some Western leaders to the parliamentary parties played a decisive role to reach the required two-thirds majority in the Parliament to ratify the Agreement (Vankovska 2020). It is therefore abundantly clear that from the Macedonian side the PA is unsustainable.

The strongest legal argument of the Macedonian government for a possible (future) unilateral withdrawal or termination of/from the PA would be its violation of the Article 53 of the Vienna Convention on the Law of Treaties ("A treaty is void if at the time of its conclusion, it conflicts with peremptory norms of international law.") As discussed earlier the right to self-determination of nation's name or a state identity represents such a norm. Moreover, the legal basis of the PA, the $\mathrm{SC}$ resolutions 817 and 845 , is in violation with the UN Charter Articles $1(2,7), 2(1)$ and 4(1) and makes the Agreement a priory unlawful according to the general legal principle ex injuria jus non oritur. Furthermore, the provisions of PA explicitly enter into the domain of domestic jurisdiction of Macedonia and are in conflict with the basic norms of international law, and establish instruments for permanent intervention into internal and external affairs of the country (Articles 
1 and 8), derogating its sovereignty and particularly its cultural and human rights. In addition to Article 53 of the Vienna Convention, the Macedonian government can also invoke other basis for withdrawal or termination of a treaty such as rule provided in article 46 (internal violations of domestic law known to the other contractor (Greece), since ratification document for PA was not signed by the Macedonian President (as provided by domestic law). Also, Macedonia can invoke termination grounds embedded in Article 48 (relating error or fallacy), claiming absence of legal knowledge of previous Macedonian government related to illegal character of the SC resolutions 817 (1993). Namely, it is now undoubtedly clear that the Macedonian government operated under assumption that there was nothing wrong with the UN resolutions 817 and 845 (1993).

In conclusion, one can observe that erga omnes norms contained in the PA for mandatory internal application of ID modifiers may not be implementable. The implementation of such modifiers in domestic legal and social order generally and finally depends on the people's will to accept (i.e. tolerate) or resist to the new imposed identity, and that imposition of alienated redefined new identity obviously does not seem durable.

The most appropriate measure of actions in the case of described illegal treaty is to terminate the PA with a diplomatic note, as an unilateral legal and political act expressing a will of the state. Such a diplomatic action could contain a justification for termination of the Agreement based on violation of the peremptory inherent rights of the State, i.e., jus cogens norm(s) enshrined in article 53 of the Vienna Convention of the Law of Treaties (related to Treaties conflicting with a peremptory norm of general international law ("jus cogens"). This course of action does not depend on the parliamentary majority and is not a subject of any domestic legal procedure(s) in the Macedonian Parliament or other branches of government, ex post facto.

\section{References}

1. Advisory Opinion of International Court of Justice (ICJ) of 28 May 1948, online https:// www.icj-cij.org/en/case/3/summaries (accessed on 23 March 2021).

2. Final Agreement for the settlement of the differences as described in the United Nations

3. Security Council Resolutions 817 (1993) and 845 (1993), the termination of the Interim Accord of 1995, and the establishment of a strategic partnership between the parties (2018), online: https://www.un.org/pga/73/wp-content/uploads/sites/53/2019/02/14-February-Letter-dated-14-February-2019.pdf (accessed on 23 March 2021).

4. Henkin Louis, Richard C. Pugh, Oscar Schachter \& Hans Smit (1993), International Law: Cases and Materials 253, 3d ed., St. Paul, Minn.: West Publishing Co.

5. Heraclides Alexis (2020), "The settlement of the Greek-Macedonian naming dispute: the Prespa agreement", Security Dialogues, 11(2).

6. Janev I. and Petrovic D. (2011), "Legal Mode for Advisory Redress at the International Court of Justice for the Case of Macedonian UN Membership", Review of International Affairs.

7. Janev I. (1999(, "Legal Aspects of the Use of a Provisional Name for Macedonia in the United Nations System", American Journal of International Law, 93(1). UN Charter, online https://www.un.org/en/about-us/un-charter/full-text (accessed on 23 March 2021).

8. UN General Assembly Resolution, A/RES/47/225 (1993), online 
9. https://www.securitycouncilreport.org/atf/cf/\%7B65BFCF9B-6D27-4E9C-8CD3CF6E4FF96FF9\%7D/UNMembers\%20ARES\%2047\%20225.pdf (accessed on 23 March 2021).

10. UNSCR (07/04/1993) Resolution 817, online https://digitallibrary.un.org/record/164660?|$\mathrm{n}=\mathrm{en}$ (accessed on 23 March 2021).

11. Vankovska Biljana (2020), "Ceopolitics of the Prespa Agreement: Background and After-Effects", Journal of Balkan and Near Eastern Studies, vol. 22, no. 3, May-June 2020.

12. Vienna Convention on the Representation of States in their Relations with the International Organizations of Universal Character, 14 March 14 1975, online https://legal.un.org/ ilc/texts/instruments/english/conventions/5_1_1975.pdf (accessed on 23 March 2021).

13. Vienna Convention on the Law of Treaties (1969), online https://legal.un.org/ilc/texts/ instruments/english/conventions/1_1_1969.pdf (accessed on 23 March 2021). 